\section{NIETZSCHE E PLATÃO: ARTE E ORQUESTRAÇÃO DAS PAIXÕES}

\section{Luzia Gontijo Rodrigues*}

RESUMO $O$ objetivo deste texto é apontar os pontos de proximidade e de diferença entre as reflexões de Nietzsche e de Platão sobre o papel da arte para o autogoverno do indivíduo e a autonomia e soberania da cultura.

Palavras-chave arte, cultura, autonomia, autodisciplina

ABSTRACT This article aims to show the points of difference and affinities between Nietzsche's and Plato's thoughts on the role of the art in the individual self-governing and sovereign of culture.

Key-words art, culture, autonomy, self-discipline

Pretende-se defender aqui a tese da existência de um permanente diálogo entre Nietzsche e Platão no que diz respeito ao sentido da arte para a cultura e seu papel na auto-educação do indivíduo. Malgrado a distância que separa 0 nascimento da tragédia da reflexão levada a cabo, por exemplo, nos fragmen tos póstumos do último ano de produção do filósofo, pode-se identificar na trajetória daquela problemática, através de duas décadas de escritos, a perma-

* Artigo recebido em jul./2003 e aprovado em abr./2004.

1 Professora da Faculdade de Filosofia do Instituto Santo Inácio (ISI-CES).

KRITERION, Belo Horizonte, ${ }^{\circ}$ 109, Jun/2004, p. 136-158 nente tentativa de resposta a - e por que não dizer de diálogo com? - seu mestre Platão, cuja postura teórica ante a arte teria marcado toda posterior reflexão filosófica que teve como objeto a obra de arte e a criação artística, na cultura ocidental.

Tenciona-se aqui abordar o pensamento nietzscheano sobre a arte em dois momentos: aquele da reflexão inicial sobre o trágico e a obra de arte apolíneodionisíaca da tragédia ática; o outro, tardio, quando já em 1888 reaparece a temática da obra de arte trágica e de seu sentido para homem e cultura, agora sob a fórmula "grande estilo". Uma síntese inicial sobre a questão da arte em Platão pretende apenas localizar o que parece ter soado para Nietzsche como um convite ao embate, no mais puro sentido em que este filósofo sempre interpretou $o$ agón grego. Ao centro da provocação platônica, a indagação sobre o lugar da arte no permanente desafio da necessária orquestração das paixões, um desafio que deve ser assumido como tarefa superior pelo filósofo-legislador, crença igualmente partilhada por Nietzsche: auto-nomos ou hetero-nomos? Encontrar-se-ia aqui o problema maior lançado pela reflexão moral grega, ante ao qual a cultura moderna estaria convidada a reiteradamente tomar posição. A questão da arte encontrar-se-ia inserida no contexto de uma discussão político-moral, mais especificamente, de legislação da cultura, na condução da qual Nietzsche se sente, sem modéstia alguma, à altura de seu mestre grego para também expor as mazelas de sua época, propondo um ideal mais elevado.2

Foi o próprio Platão a chamar a atenção para a existência de "um grande combate" (608b), ${ }^{3}$ aquele travado entre a razão e a imagem, entre o discurso racional e as artes (miméticas), o "antigo diferendo entre a filosofia e a poesia" (607b), o qual, sem a menor dúvida, marcará dois milênios de reflexão sobre a arte. De uma forma que se pode considerar perversa, serão as artes mesmas a incorporarem os critérios instituídos por esse discurso que estabelece a oposição, aceitando princípios heterônomos e tentando responder às condições impostas por uma ordem que nunca foi a sua, aquela do discurso racional sobre o real, conformando-se, assim, às exigências do reconhecimento teórico. 4

2 Quanto a Nietzsche leitor de Platão: Nietzsche deixa claro que Platão é essencialmente filósofo-legislador, sua grande questão filosófica estando enraizada no territorio ético-político. Se Platão recusa o real, ele não o ignoraria, mas sim o julgaria, pois ele não quer o que vê a sua volta, daí sua força para construir um ideal. Que Nietzsche admirava profundamente e se espelhava nesse Tipo e na sua força, pode-se constatar, por exemplo, na leitura de seus cursos sobre Platão: Cf. NIETZSCHE. Vorlesungsaufzeichnungen (WS 1871/ 72-WS 1874/75). In: Nietzsche Werke. Kritische Gesamtausgabe. Zweite Abteilung. Vierter Band, 1995; ainda "Richard Wagner in Bayreuth". KGW IV 1, \& 7, p. 40-41. Sobre o tema, cf. a interessante leitura de Monique Dixsaut: DIXSAUT. Nietzsche Iecteur de Platon, p. 295-313.

PLATÃO. A Republica. 8. ed. Livio X, p. 477. Todan as c obra estarão entre parêntesis, no próprio texto. 
Será justamente pela problemática do reconhecimento do real e das possibilidades de construir sobre este um conhecimento que, por sua vez, traduza o homem para o próprio homem, o lugar por onde Platão começa seu discurso mais conhecido e divulgado sobre a arte: a consciência ante o mundo que a cerca e o reconhecimento de si mesma como alteridade. $\mathrm{O}$ conceito de mímesis será ponto axial da teoria platônica da arte e alavanca- mestra de sua condenação dos poderes artísticos. O Livro X de A República oferece-nos uma síntese esclarecedora do sentido de tal condenação, ao deixar explícito o reconhecimento, por parte do filósofo, do poder desenvolvido pela arte de seu tempo para criar ilusão. Mas não apenas aí são encontrados elementos que remeteriam àquele "grande combate".

Uma passagem do Livro III pode servir para aproximar Nietzsche e Platão, no que diz respeito à discussão dos vínculos entre a arte e os fundamentos da cultura. Sugestivo aqui o fato de o diálogo girar em torno da música (398c-403), para Nietzsche a mãe de todas as artes,' e da educação pela música, um tema crucial, já que beleza e harmonia são essencialmente questão de ritmo, como nos lembra Platão (400d-402a). E ritmo musical, assim como harmonia, são expressões que dependem do caráter da alma, "logo a boa qualidade do discurso, da harmonia, da graça e do ritmo depende da qualidade do caráter, não daquele a que, sendo debilidade de espírito, chamamos familiarmente ingenuidade, mas da inteligência que verdadeiramente modela o caráter na bondade e na beleza" (400e). Beleza e fealdade pertencem igualmente ao mundo, sendo que cada uma delas carregaria consigo as formas correspondentes de caráter, à fealdade sendo congênitas as formas da arritmia, da desarmonia, do mau caráter; por outro lado, as qualidades opostas correspondendo a imitações do inverso, que é o caráter sensato e bom (401a).

Ora, justamente porque o caráter humano é moldável, plástico e mimético, o artista e as artes estariam muito próximos daquilo que se poderia denominar "educação do caráter", podendo mesmo ser confundidos com essa "for-mação" essencial anímica. Justamente porque a alma é matéria maleável à espera do trabalho escultórico proporcionado por aqueles e aquilo que, numa sociedade, assumem a tarefa do cinzel educador, deve-se dedicar especial desvelo a esses poderes modeladores, se queremos impedir o domínio do vício, da baixeza, do que é menor e menos digno da grandeza possível ao humano (401b-c). Grande deferência essa dirigida pelo filósofo à arte, admitindo ser esta a mais próxima potência educadora a se igualar à própria filosofia, talvez por partilharem uma gênese comum. Menos do que um repúdio às artes como o todo, como vimos anteriormente, o filósofo exerce sua força legisladora em relação à cultura para estabelecer discernimentos, no caso da arte, procurando distinguir o que aí aponta para o perigo da dissolução, o que para a maestria do caráter.

São duas as principais acusações de Platão à arte, ambas constituindo-se, no fundo, do mesmo repúdio a um território nebuloso e pouco definível instalado pelo artístico, território no qual conceitos como verdade e não-verdade, ser e não-ser mostram-se inócuos e de pouca eficácia. A primeira acusação é a de que o poder da mimesis cria objetos e seres que não existem, mas que são apenas "objetos aparentes, desprovidos de existência real" (596e), como seria o caso do pintor. Esse artista criaria uma cama ou um sofá, tentando imitar os que existem na natureza e que foram obras de um artífice, o marceneiro, o qual, por sua vez, criou tais objetos tendo como modelo a Idéia de sofá ou cama. Portanto o marceneiro, ao produzir objetos, tenta copiar a Idéia de sofá ou cama, tal como estes foram concebidos por Deus, enquanto Idéia imutável, eterna, sempre igual a si mesma. No entanto, o pintor, ou outro artista mimético, tenta imitar não a Idéia, pois ele não reproduz a realidade "como ela realmente é" (598b), mas como ela aparece, sua aparência. Platão pode assim concluir que "a arte de imitar está bem longe da verdade, e se executa tudo, ao que parece, é pelo fato de atingir apenas uma pequena porção de cada coisa que não passa de uma aparição" (598b).

Pode-se melhor compreender o argumento desenvolvido por Platão a respeito desse caráter do artístico de "atingir apenas uma pequena porção do real" quando se considera o que significou a invenção da perspectiva e da ilusão de ótica na pintura, conjugados estes dois artifícios com a descoberta do escorço e do modelado em luz e sombra. ${ }^{6}$ Todos esses "truques" foram inventados pelos gregos e passarão a fazer parte do vocabulário artístico da arte ocidental até nossos tempos, mesmo considerando seu repúdio pela arte medieval de influência bizantina. A perspectiva em especial parece encaixar-se perfeitamente nesse argumento de Platão contra a arte: o artista descobre e fascina-se com a possibilidade de mostrar um objeto ou corpo a partir de um ângulo ou ponto de vista determinado. Assim é que ele poderá mostrar as coisas mais como elas parecem a um olhar determinado do que como são, de acordo com a observação de Platão (598a), ou seja, não como elas são de acordo com a

6 Cf. GOMBRICH. Arte e ilusão. Especialmente o capítulo "Reflexões sobre a revolução grega". Cf., também, PANOFSKY. "A história da teoria das proporções humanas como reflexo da história dos estilos" In: Significado nas artes visuais, p. 89-148. 
Idéia, o conceito, em sua inteireza e imutabilidade, mas apenas como aparecem ao olhar, de um determinado ângulo de visão.7.'

Pierre-Maxime Schuhl, em sua obra sobre Platão e a arte, destaca a atitude severa do filósofo ante os "modernos" como parte de sua desconfiança em relação a toda mudança, sempre associada ao que de mais perigoso existiria no mundo, trate-se das estações do ano, dos ventos, dos regimes do corpo ou das disposições da alma.' Mais ainda do que as instabilidades ameaçadoras da natureza, aquelas responsáveis por mudanças de hábitos podem conduzir a perigosas oscilações dos sentimentos: não se altera um gênero musical sem se provocar abalos nas mais altas leis da cidade.' Com muita propriedade aquele autor chama a atenção para o fato de Platão estar, aparentemente, estendendo para o território artístico concepções da medicina hipocrática acerca da influência do meio sobre o caráter, o que nos conduziria à evocação do estilo severo das estelas funerárias do século $\mathrm{V}$ a.C. ou dos frontões do templo de Zeus em Olímpia, onde parecem imageticamente estampados os princípios éticos do "nada em demasia".' ${ }^{\circ} \mathrm{Em}$ ambos os casos a arte exaltaria a contenção das emoções e o autodomínio sobre as emoções mais violentas, justamente fazendo face $\mathrm{O}$. reprovação de Platão ao teatro por encenar preferencialmente personagens que não sabem dominar suas paixões."

Tal atribuição à arte de poderes modeladores do caráter estará igualmente ao centro das reflexões nietzscheanas da cultura. Mesmo que isso pareça dissonante com a conexão reiteradamente autorizada por Nietzsche entre seu nome e o do deus Dioniso, ${ }^{12}$ vamos aqui insistir na tese de que isso não deve nos ocultar a proximidade, por vezes até surpreendente, entre os questionamentos dos dois filósofos em torno da arte.

7 Panofsky chama a atenção para a muito conhecida história de uma Atená de autoria de Fídias, em que a parte inferior da estátua era demasiado curta em relação à superior, mas que, no entanto, parecia aos olhos de seus observadores como perfeitamente proporcional, já que a estátua fora colocada em um nível bem acima dos olhos. Tal princípio da correção ótica foi uma das sobre Platão e a arte de seu tempo, remete-nos a um trecho do Sofista (235d-236c), no qual Platão faz referência aos artistas que,

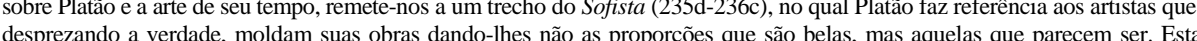
desprezando a verdade, moldam suas obras dando-lhes não as proporções que são belas, mas aquelas que pare
mesma passagem do Sofista é citada em nota por Panofsky. Cf. SCHUHL Platon et I'art de son temps, p. 4. mesma passagem do Sofista é citada em nota por Panofsky. Cf. SCHUHL
8 Cf. SCHUHL, op. cit., p. 12-13. 0 autor cita aqui uma passagem de Leis Vll. 9 Cf. A República, Livro IV, $424 \mathrm{c}$.

10 Sobre a correspondência entre rigor estético e ético, cf. POLLITT. Art and experience in classical Greece, especialmente o capitulo "Conciousness and conscience"; p. 15-63. Nietzsche dirá em $O$ nascimento da tragédia § 4, "Apolo, enquanto divindade ética, exige mesura dos seus, e, para poder mantê-la, conheci-mento de si mesmo. E, assim, a exigência do 'conhece-te a ti mesmo' e o 'nada em demasia' caminha paralela à necessidade estética da beleza [...]." 11 SCHUHL, op. cit., p. 16-17. Quanto à critica de Platão ao teatro, cf. A República, Livro X, 604

12 Cf. NIETZSCHE. Ensaio de autocrítica. In: Nietzsche, F. Sämtliche Werke. Kritische Studienausgabe (KSA),

v. I;. El nacimiento de la tragédia. 8. ed. Cf. também Crepúsculo dos ídolos (GD): "O que devo aos antigos", § 5, In: KSA VI, p. 160
Tudo tem seu início no esforço de Sócrates para conduzir seu interlocutor, Gláucon, ao entendimento do porquê, na fundação da cidade mais perfeita, ser de crucial importância uma doutrina sobre a poesia que recuse em absoluto "a parte da poesia de caráter mimético" (595a). A interrogação do discípulo sobre o que quer dizer mimesis servirá ao filósofo como oportunidade para expor sua doutrina sobre todos os simulacros de aparência, construindo um discurso que atrai a imagem para o terreno das estruturas de linguagem próprias à filosofia, para interrogá-la a partir de pressupostos próprios a tal linguagem. O exemplo escolhido é eloqüente: o de um artífice-mago cujo poder não passa de manipulação de espelhos. ${ }^{13}$ "Efetivamente, não só é capaz de executar to-dos os objetos, como também modela todas as plantas e fabrica todos os seres animados, incluindo a si mesmo, e, além disso, faz a terra, o céu, os deuses e tudo quanto existe no céu e no Hades, debaixo da terra" (596c). Ante o espanto de seu interlocutor de que possa existir tão sobre-humana capacidade, Sócrates esclarece não ser difícil executar isso de maneira até mesmo rápida e varia-da, "muito rápida mesmo, se quiseres pegar num espelho e andar com ele por todo o lado. Em breve criarás o sol e os astros do céu, em breve a terra, em breve a ti mesmo e aos demais seres animados, os utensílios, as plantas e tudo quanto há pouco se referiu" (596d/e). A contestação de Gláucon ante tal sugestão é sintética, replicando que todavia estes "são objetos aparentes, desprovi-dos de existência real". Era a deixa que Sócrates precisava para introduzir o nome do pintor, esse artífice que, como veremos na seqüência, usaria suas habilidades de prestidigitador para enganar-nos acerca da verdade, criando "aparições".

Seria conveniente uma pausa na análise direta do texto para que seja enfatizado algo fundamental, já que se pretende justamente o confronto de tal discurso com as reflexões nietzscheanas sobre a arte. Não se pode perder de vista o fato de Platão estar aqui protagonizando uma luta político-ideológica ${ }^{14}$ com os sofistas, e não apenas no sentido restrito desse termo, mas contra todos que, por suas habilidades artísticas ou de discurso, fariam apologia da indistinção

13 SCHUHL comenta que a palavra grega empregada por Platão para "cor" designa igualmente as drogas dos feiticeiros e médicos, acrescentando uma observação recorrente em textos de estética sobre o caráter mágico das reproduçõos
artísticas, fato evidente para as culturas da Antigüidade, mas que muitas vezes passa despercebido de nós modernos: o
artista é identificado ao mágico que seduz por sortilégios. SCHUHL cita passagens do Crátilo (424 e) e de A República artista é identificado ao mágico que seduz por sortilégios. SCHUHL cita passagens do Crátilo o (424 e) e de A República
(Livro IV $420 \mathrm{c}$; Livro X 598 d). Jacqueline Lichtenstein remete exatamente a esta última passagem de A República, mostrando como pintores e sofistas são identificados por Platão a "lançadores de poeira nos olhos", ou seja, são perfeitos técnicos do disfarce e mestres do engano. Cf. SCHUHL, op. cit., p. 22; LICHTENSTEIN, op. cit., p. 60. Cf. também GOMBRICH, op. cit., especialmente o capitulo "O poder de Pigmalião" 
entre verdade e mentira. ${ }^{15}$ Como ironiza Gláucon, são sábios de espantar esses homens capazes de fabricar todas as coisas. ${ }^{16}$ Apesar da ironia implícita, Platão deixa-nos entrever aqui o quanto sua intolerância para com os "produtores de imagens" oculta sua admiração.

Deve-se reconhecer que se evidencia nas criticas platônicas aos poderes extraordinários da magia mimética o reconhecimento de seu duplo caráter: a imagem seria esvaziada de ser, de verdade e, ao mesmo tempo, detentora de um poder extraordinário." Apesar de três graus distante do ser verdadeiro (597e); apesar de ser classificada como mero fantasma a ludibriar crianças e pessoas ignorantes (598c), a imagem mostra toda sua força e poder, já que é capaz de ameaçar a lei e a razão, permitindo que um homem ou uma cidade sejam governados pelo irracional que neles habita e que só pode conduzi-los a muita dor e aflição (604a-606d). Dessa forma, a mimesis seria responsabilizada por oferecer apenas ausência, falta, simulacros, aparências e, ao mesmo tempo, por seus poderes excessivos, sua força extraordinária de arrebatamento e convencimento para o mal.

Está assim armado o cenário no qual a própria arte assumirá, ao longo dos dois milênios seguintes, o papel que the é conferido pelo discurso do filósofo: o de mera reprodutora do real, espelho da natureza, senhora de uma verdade que não lhe pertence, já que seus "produtos" (imagens) serão sempre considerados em função de uma outra realidade tida como originária, à qual ela deverá prestar reverência, até mesmo nos momentos em que ousou lhe voltar as costas. A natureza e o real impõem-se como referência a partir da qual a imagem deve ser não apenas apreciada, mas também julgada. A História da Arte e, mais tarde, a Estética, nascida no século XVIII com Alexander Baumgarten (1714-1762), estarão marcadas por essa metáfora que identifica a criação artística ao "efeito" de um espelho do real, ao menos até o surgimento do romantismo no século XIX .18

Para o objetivo aqui proposto, aquele de apontar na critica da arte de Platão pontos cruciais para a reflexão nietzscheana, seria pertinente compreender

15 Cf. LICHTENSTEIN, op. cit., p. 13 e 55-56, onde a autora enfatiza que as análises da mimesis pictórica no Livro X, de A República, teriam a finalidade estratégica de, através da pintura, visar à sofística. Em mais de uma passagem de sua obra, a autora analisa essa atitude da crítica platônica que ora condena a sofística por sua semelhança com a pintura, ora rejeita est por analogia à sofística, apontando para os diálogos: Górgias; O Sofista; Crátilo, além de A República. Cf. especialmente o 16 Cf. Livro X, 596 d. A tadutra da. Da comenta em nota que a p-61.

Cf. Livro X, 596 d. A tradutora da obra comenta em nota que a palavra grega aqui empregada por Platão

para "sábio", teria originado o termo "Sofista". Até o séc. V a.C. ela teria tido o sentido equivalente ao de "sábio", mas quando os Sofistas usam o termo para se qualificarem, ele cai em descrédito.

18 Cf. HERRERO. Estética. Em especial p. 147-148 e 258-261. o alcance dessa primeira acusação feita ao pintor de ser mero "imitador do real", pois sob tal formulação oculta-se todo um universo de atividades e experiências humanas, todas tendo em comum o fato de existirem à custa do artifício, do disfarce, da máscara, do ornamento e da mentira. ${ }^{19} \mathrm{Um}$ dos engodos dos quais a alma se tornaria prisioneira quando seduzida pelas imagens criadas por pintores, lembra Sócrates a seu interlocutor, seria aquele de tomar uma pequena porção de cada coisa por sua totalidade (598b), já que aqueles artífices da imagem buscam apenas imitar as coisas como elas nos aparecem a partir de um determinado ângulo de visão, e não como elas realmente são. "Por conseguinte, conclui Sócrates, a arte de imitar está bem longe da verdade, e se executa tudo, ao que parece, é pelo facto de atingir apenas uma peque-na porção de cada coisa, que não passa de uma aparição" (598b), o que parece apenas reproduzir a parcialidade da visão de uma pessoa, se esta olha, por exemplo, uma cama de lado, ou de frente, ou de qualquer outro ângulo, percebendo a cada momento uma cama diferente de si mesma, mesmo quando sabe-mos que ela não o é (598a). ${ }^{20}$

A esta altura já se pode perceber que a crítica ao artifício operado pelas artes miméticas visa alertar contra o perigo, para a consciência, da perturbação das identidades. Seja em nome da virtude ou do conhecimento correto, o artifício será sempre acusado, a partir desse alerta de Platão, de não respeitar as distinções necessárias para o domínio do indivíduo senhor de si. Graças aos truques artísticos operados pela mimesis, a imagem carregaria um duplo efeito: por sua "falta essencial de ser" ${ }^{21}$ representaria um perigo à identidade e ao conhecimento do real; por sua força para iludir e enganar seduzira a consciência, desviando-a do reto caminho que demarcaria realidade e não-realidade. Ao reconhecer a força arrebatadora do mimético, o alerta de Platão contra os perigos da sedução da imagem evidenciaria a preocupação do filósofo com toda experiência que coloque o homem ante o perigo da perda de si, assim como com toda aquela que represente risco à reta condução da cidade. 19 Cf. LICHTENSTEIN, op. cit., especialmente o capitulo "Da toalete platônica", onde a autora chama a atenção para o fato
de que essa acusação lançada por Platão ao pintor teria a finalidade estratégica de alcançar a sofística: a sofística seria de que essa acusação lançada por Platão ao pintor teria a finalidade estratégica de alcançar a sofística: a sofíi
condenada por sua semelhança com a pintura, e a pintura rejeitada por analogia à sofística, cf. op. cit., p. 55-56.

20 Neste ponto fica muito claro aquilo que Gombrich diz ter sido a reação de Platão à arte de seu tempo, já que a arte grega inventara a perspectiva no século $\mathrm{V}$, possibilitando imagens que cada vez mais dificultavam uma distinção entre verdade e mentira. Gombrich cita várias passagens conhecidas na história da arte de narrativas de Plínio e Quintiliano sobre o
espanto ante essa epopéia de conquistas da arte grega, entre essas estaria aquela já famosa sobre uma pintura de Zêuxis espanto ante essa epopéia de conquistas da arte grega, entre essas estaria aquela já famosa sobre uma pintura de Zêuxis
reproduzindo uvas que enganavam até mesmo os pássaros que vinham prová-Ias, cf. GOMBRICH, op. cit., especialmente reproduzindo uvas que enganavam até mesmo

O capítulo "Reflexões sobre a re
21 Cf. GAGNEBIN, op. cit. , p. 83. 
A questão da distinção entre imagem e real, entre ilusão e verdade, entre engano e certeza, com todas as suas derivações como aquela da necessária diferenciação entre ornamento e artifício, segundo a qual todo ornamento, se em excesso, corre o risco de tornar-se mero disfarce da verdade, "mero ornamento" 22 - que margeiam as discussões sobre a arte; todo esse território, onde se misturam conceitos metafísicos, éticos e estéticos na tentativa de se estabelecer distinções claras entre verdade e não-verdade, encontra-se assentado sobre a necessidade de assegurar ao indivíduo pleno domínio das referências que the permitam reconhecer a si mesmo como senhor de si e da realidade que o cerca. O grande perigo da ilusão é aquele de o indivíduo, de o sujeito da percepção, incorporar para si o estatuto de ser fictício, perdendo não apenas a certeza das coisas, não apenas as referências que lhe permitiriam distinguir um sofá pintado de um sofá real, mas, muito mais grave, perdendo a certeza de si próprio, ao experimentar o prazeroso sentimento de "não realização", quando percebe vacilarem todos os dispositivos que garantiam e determinavam as identidades. ${ }^{23}$ Que se pense aqui na bela imagem oferecida por Schopenhauer e apropriada por Nietzsche em $O$ nascimento da tragédia, descrevendo o permanente risco da dissolução do principium individuationis, que ameaçaria aquele que pode contar apenas com sua frágil embarcação no enfrentamento com os horrores de um mar tempestuoso. ${ }^{24}$

Justamente nesse ponto, aquele que se refere aos desafios enfrentados pelo homem para se tornar senhor de si, percebe-se a sobreposição das duas críticas de Platão aos poderes do mimético. Pode-se agora visualizar a segunda acusação feita à arte, aquela que apontaria para os efeitos aí produzidos no sentido de alimentar a discórdia e a contradição na alma, quando imita homens entregues a ações ou pensamentos conflituosos, promovendo o desacordo do homem consigo mesmo. Tal efeito se assemelharia àquele produzido pelos truques da perspectiva, enganando o homem sobre aquilo que ele julgaria ver. Em todas essas ocasiões produzidas por poetas e pintores, pergunta Platão, estaria porventura o homem "de acordo consigo mesmo? Ou, tal como sofria de dissensão interna relativamente à visão, e albergava ao mesmo tempo opiniões contrárias sobre os mesmos assuntos, do mesmo modo, no seu compor tamento sofre de dissensão e luta consigo mesmo?" (603d).

Além de executar suas obras "longe da verdade", a pintura, a poesia, todas artes miméticas de um modo geral, colocam-nos ante a parte em nós mes- mos mais distante do bom-senso (603b), do razoável e da lei e, no entanto, insiste Platão, a melhor parte de nós seria aquela que quer seguir a razão, sendo a outra aquela "que nos leva à recordação do sofrimento e aos gemidos e que nunca se sacia deles" (604d). Essa parte fraca, irracional, propensa à covardia, mostra-se exatamente como material perfeito para a imitação, "ao passo que o caráter sensato e calmo, sempre igual a si mesmo, nem é fácil de imitar nem, quando se imita, é fácil de compreender", sobretudo quando se trata da arte produzida para os festivais dramáticos, em que se apresentavam as tragédias (604d1e).

Aos riscos de mergulharem o homem em "mar tempestuoso", retirando lhe quaisquer possíveis pontos de apoio para a distinção entre real e ilusório, deve-se ainda acrescentar sobre os artifícios miméticos serem eles responsáveis por instaurar na alma de cada indivíduo um mau governo, lisonjeando a parte irracional, que não sabe distinguir diferenças, permitindo que as paixões assumam o controle $(605 \mathrm{~b} / \mathrm{c})$ e, portanto, colocando a perder todo o trabalho pedagógico fundamental, seja para o governo da cidade seja para o do homem sobre si mesmo. Ora, lembra Sócrates ao jovem aprendiz, se levarmos em consideração que aquela parte da alma que há pouco contínhamos pela força, nos nossos desgostos pessoais, num exercício imperioso de autodomínio e autoconhecimento, impedindo que ela se perca em sua sede de gemidos e lá-grimas, será justamente a mesma que poetas e artistas miméticos em geral se incumbirão de alimentar para a satisfação e o regozijo (606a), então percebe-remos melhor os efeitos que em nós produz a imitação poética: nossos monstros tornam-se nossos senhores no exato momento em que o amor, a ira e todas paixões aprazíveis ou penosas da alma são regados, quando deviam ser seca-dos (606d). ${ }^{25}$

Esse o mais antigo diferendo entre a filosofia e a poesia (607b), admite Platão, um combate a ser travado pela "pedagogia do autogoverno", em nome do qual é preciso alertar os jovens e defender a cidade, não permitindo que em seu seio se instale aquele efeito de licenciosidade da alma para consigo mesma, da lei para como seu objetivo, da razão em relação a seu objeto, que põe a perder o que de melhor a nossa natureza possuiria, aquela propriedade da vigilância sobre os desvios e as fraquezas, a justa medida que nos ensina o domínio sobre o que ameaça fugir ao controle. Se, no entanto, permitimos que a

25 Eis aqui a questão-mor estóico-platônica da orquestração de si: a filosofia como terapêutica das paixões assume a tarefa da educação do homem. Que se atente ao fato de não se tratar aqui de uma simples tentativa de se construir um saber teórico, mas sim de propor uma transformação profunda do homem envolvendo toda a sua personalidade, sua existência, seu modo de vida: cf. HADOT. Exercices spirituels et philosophie antique. 
"Musa aprazível na lírica ou na epopéia" seja acolhida na cidade ou na alma juvenil seduzida, então o governo estará aí entregue ao prazer e à dor, em lugar da lei e do princípio do "justo meio", que é aquele estabelecido a partir do consenso e da medida (607a). Esse, concordará Nietzsche, o "grande combate" no qual a filosofia certamente precisa insistir, se quer assumir sua missão legisladora-educadora: em jogo estaria aquilo de imortal, prisioneiro de uma natureza sujeita à corrupção, à degeneração e à morte.

O texto de Platão exala a ambigüidade dessa condenação que é ao mesmo tempo confissão de um seduzido. Mais de uma vez ele insiste em que precisamos de toda cautela para com as seduções exercidas sobre nós pelo mimético; em como a poesia e as artes em geral estão voltadas para o prazer; em como elas exercem um encantamento sobre nós. O ápice dessa confissão indireta de amor à arte fica por conta da passagem emblemática na qual os efeitos amorosos provocados pela arte são comparados àqueles exercidos sobre nós pelas paixões mundanas, igualando-se o esforço para seu combate e o reconhecimento do seu poder. ${ }^{26}$ No que diz respeito a Nietzsche, não são menores as ambigüidades que marcam sua filosofia no que diz respeito à arte, sendo o mais eloquiente exemplo disso o lugar aí ocupado por Dioniso e o aparente "esquecimento" de Apolo, quando se confronta uma obra como O nascimento da tragédia com os escritos tardios sobre o tema.

Falar da arte e do impulso artístico na obra de Nietzsche remete invariavelmente ao nome de Dioniso. E isso serve tanto para sua primeira obra sobre a tragédia grega quanto para as reflexões tardias, mais especificamente aquelas localizadas entre "Ensaio de autocrítica" escrito em 1886 para uma nova edição de O nascimento da tragédia - e os últimos escritos póstumos de 1888 . No entanto, justamente aqui seria preciso redobrar a atenção para o reaparecimento do nome desse deus na obra de maturidade, evitando lê-lo tal como se lia aquele Kunsttrieb (impulso artístico) em perpétua luta e conciliação com seu contrapar, o impulso artístico apolíneo, da forma como os apresentou $O$ nascimento da tragédia. ${ }^{27}$ Se Dioniso volta a emergir na obra tardia, estranhamente o nome de Apolo desaparece por completo, ${ }^{28}$ oferecendo já um indício de que aquela oposição não faz mais sentido para a nova conformação criada para o deus trágico grego. É preciso admitir que a imagem atribuída agora, na década de oitenta, a este deus chega, por vezes, a causar estranhamento e mesmo indignação aos mais radicais admiradores de sua face báqui-

26 Cf. PLATÃO. A República. Livro X: 601 b; 607c; 608a.

27 Cf. O nascimento da tragédia (GT) $\S 1 e 2$. KSA I. Todas as citações de Nietzsche utilizadas aqui têm como base esta ca. É preciso reconhecer como desafio o exercício de se tentar compreender a permanência do questionamento acerca do significado da arte — ou para falarmos muito adequadamente nos termos de Platão, dos efeitos dos artifícios miméticos para homem e cultura — na trajetória que vai de $O$ nascimento $d a$ tragédia aos escritos que, em 1888 , retomam a reflexão inicial sobre esta obra. ${ }^{29}$

A questão da arte em $O$ nascimento da tragédia parece concentrar-se o tempo todo em torno de um eixo que oscila entre dois impulsos simultaneamente antagônicos e complementares: aquele para a delimitação do que é único e singular, que impõe rígidos contornos a delimitar cada particularidade, por um lado, e aquele para a dissolução dos contornos individuais, graças ao qual desaparecem todos os limites do subjetivo e do único, conduzindo mesmo a um efeito letárgico de esquecimento, pela aniquilação das referências que permitem a identidade. Num importante fragmento póstumo de 1888, o filósofo retoma o núcleo fundamental dessa narrativa tecida com os nomes das duas divindades, ou ao menos daquilo que agora lhe aparece como tendo sido o essencial de sua invenção dos gregos. Tratando-se na terceira pessoa, talvez traindo sua condição de criador de uma bela ficção, Nietzsche explica a razão de ter escolhido Apolo e Dioniso para traduzir em imagem uma certa "sabedoria para a totalidade" presente na vivência grega com a arte, ou ao menos naquilo que ele erigiu e privilegiou como "a vivência grega com a arte":

Essa oposição do dionisíaco e apolíneo dentro da alma grega é um dos grandes enigmas, pelo qual Nietzsche se sentiu atraído diante do ser grego. No fundo Nietzsche se esforça para adivinhar, porque exatamente o apolinismo grego precisou brotar a partir de um fundo para adivinhar, porque exatamente o apolinismo grego precisou brotar a partir de um fundo
(Untergrund) dionisíaco: o grego dionisíaco teve necessidade de se tornar apolíneo, quer dizer: de quebrar sua vontade de monstruoso, de múltiplo, do duvidoso, de horrível em uma vontade de medida, de simplicidade, de enquadramento na regra e no conceito (Einordnung in Regel und Begriff). A desmedida, deserto, asiatismo, jaz em seu fundo: a coragem do grego consiste na luta com seu asiatismo: a beleza não é para ele um presente, assim como a lógica, como a naturalidade dos costumes - ela é conquistada, querida, fruto de luta - ela é uma vitória $\left[\ldots . .{ }^{30}\right.$

Essa breve passagem deixa entrever qual o sentido para Nietzsche do emprego dos nomes de dois deuses gregos ligados à arte: não formas de arte

29 Cf. a série de fragmentos póstumos datados entre novembro de 1887 e o inverno de 1888, nos quais Nietzsche retoma sua reflexão em torno do trágico e mesmo diretamente sua obra GT. Esta série concentra-se basicamente entre os Fragmento Póstumos 14 [14] e o 17 [3], embora encontremos um Fragmento como o 11 [415], anterior a estes e abordando a mesma temática. Cf. KSA XIII. Para uma análise destes fragmentos, cf. COLLI, Giorgio. Die nachgelassenen Fragmente von Herbst/Winter 1887/1888; Die nachgelassenen Fragmente von Anfang 1888 bis Januar 1889. In: KSA XIII, p. 655-668 Também Heidegger, em sua obra sobre Nietzsche aborda essa retomada de GT, cf. HEIDEGGER. Nietzsche. v. I. p. 85

30 Fragmento póstumo 14 [14], da primavera de 1888. In : KSA XIII, p. 225 
por elas mesmas, mas sim determinações que nos reconduzem a uma problemática humana essencial. Trata-se aqui da luta entre uma "vontade de monstruoso", de múltiplo e de ausência de medida, por um lado, com a imperiosa necessidade de enquadramento na regra do conceito e da lei, por outro. Uma luta que remete a todo esforço humano e da cultura para defender o Individuum $^{31}$ das ameaças de dissolução no nada, da perigosa sedução de se deixar perder na totalidade do que é indiferenciado, desmemoriado, desistido de si mesmo. Imageticamente estampada nesse embate entre impulso apolíneo para forma e delimitação e impulso dionisíaco para dissolução no informe, para a ruptura de todas as medidas e linhas demarcatórias encontra-se a temática maior do confronto universal do homem com o destino - questão trágica por excelência ${ }^{32}$ - , confronto esse que lhe exigirá um permanente e árduo aprendizado na orquestração das forças que o atravessam, que nele habitam, que de fora o ameaçam.

Ao longo de $O$ nascimento da tragédia, Apolo é identificado às forças artísticas profilático-curativas ${ }^{33}$ responsáveis pelas formas delimitadoras do Estado, da lei e de tudo mais destinado a proteger o homem dentro dos limites da cultura, contra as forças avassaladoras da natureza e do mundo da própria interioridade humana. Graças ao poder artístico apolíneo, o homem seria levado a experimentar — seja pelo sonhar, seja pela contemplação estética - o distanciamento de si mesmo necessário para se reconhecer como distinto de tudo mais, sem que, no entanto, isso represente ameaça a sua inserção na realidade cotidiana. Ocorreria aqui um misterioso efeito mágico-mimético de identificação no distanciamento: a "bela aparência dos mundos oníricos" permitiria ao homem se reconhecer como artista completo, já que através de suas imagens ele goza na compreensão imediata da figura (unmittelbares Verständnis der Gestalt), todas as formas atingindo-o sem intermédios, nada ali sendo inecessário ou indiferente. 34

Transita-se aqui pelo território da magia mimética transfiguradora de mundos e sentidos, uma magia que, entretanto, sob o poder profilático-c ${ }^{\text {ura }}$ dor apolíneo para envolver o homem com o "véu de Maya" 35 da bela aparên-

31 Lembramos que o termo Individuum refere-se àquele que não pode ser dividido.

32 Cf. SALAQUARDA. Einleitung. Nietzsche und Wagner- Dritte Nietzsche-Werkstatt Schulpforta. In: Gerlac ${ }^{\text {hh }}$ HansMartin/Eichberg, Ralf/Schmidt, Hermamm J. (org). Nietzscheforschung. v. 2., p. 145-152.

33 Nietzsche atribui ao apolíneo "efeitos salvadores e auxiliadores", seja através do sonho seja atraveśs das artes, que seriam, segundo ele, "as que fazem possível e digna de ser vivida a vida", cf. GT § 1. Deve-se observar que tal "poder medicinal" atribuído a Apolo já podia ser identificado em Platão, mas não apenas nele como na tradição mítica grega muito anterior a ele. Cf. CONFORD. Principium Sapientiae $-A_{4}$ origens

pensamento filosófico grego. 2. ed. Cf. especialmente o capitulo intitulado "O xamanismo", p. 34 Cf. GT \& 1, KSA I, p. 26.

35 Cf. GT § 1, KSA I, p. 28 cia, ensina-lhe como exercitar sua capacidade plástica de criar e se aventurar no novo, sem com isso perder as referências fundamentais das virtudes garantidoras da autonomia e singularidade do indivíduo. ${ }^{3 o ́}$ Para Nietzsche, teria sido justamente graças a essa "sabedoria artística" profilático-curativa de Apolo que os gregos puderam vivenciar de perto a invasão de seu território pelas festividades bárbaras do dionisíaco, trazidas por cultos e festividades orgiásticos, já conhecidos em todas as partes do mundo antigo, e que passam a ser assimilados pela cultura grega. $\mathrm{O}$ fator de desequilíbrio e perigo representado por essas festividades de "geografias asiáticas" consistia na irrupção, por elas incentivada e ensinada, de todos os "monstros" habitantes da interioridade humana e dos confins da natureza, até então zelosamente mantidos à distância ou domesticados, seu centro constituindo-se geralmente em um transbordante desenfreio sexual, cujos influxos ameaçariam as estruturas protetoras do indivíduo: a lei, o Estado, a família e seus "estatutos veneráveis". 37

Nietzsche irá enfatizar justamente o caráter de ruptura e dissolução dos limites impostos pela civilização ao indivíduo, como a parte central dessas festividades, cuja força passava por cima de todas as instituições e estatutos da cultura e do Estado, pois "aqui eram desencadeadas as bestas mais selvagens da natureza", até se atingir uma perigosa mescla de volúpia e crueldade. ${ }^{38}$

Eclode em tais manifestações uma espécie de "sabedoria primitiva", instintiva, que parece herdada de uma origem imemorada e transmitida, através da evolução das espécies, por mecanismos não lingüísticos e não racionais, vivenciada numa esfera limítrofe entre natureza e cultura. Celebra-se justamente a ruptura dos contornos da cultura e a proximidade com a barbárie e o horror, próprios a um mundo do para-além ou para-aquém da civilização e suas conquistas: sob a magia do dionisíaco, lembra-nos Nietzsche, desaparece o subjetivo, até se chegar a um completo esquecimento de si. $^{39}$

Não resta dúvida de que essa vivência mágico-mimética do dionisíaco ameaça profundamente homem e cultura. Nesse sentido Nietzsche está em sintonia com a conclusão austera de Platão, ao apontar os riscos que tal vivên-

36 Virtú ou Tüchtigkeit ambos os termos empregados por Nietzsche no sentido da "virtude única", esculpida pelo indivíduo, sempre associada às idéias de excelência humana, de domínio sobre si próprio e sobre suas possibilidades, de "criação de si" como imposição de limites ao caos daquilo de que se é feito. Cf. A

gaia Ciência (FW), § 120, 290 e 335; Humano, demasiado humano I (MAI). "Prólogo" § 6; nos escritos Póstumos: 10 [109], [110]e[111]. In: KSA XII, p. 517-20; 14 [61]. In: KSA XII, p. 246-48. Cf. também BROBJER. Nietzsche's ethics of

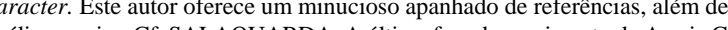

análise precisa. Cf. SALAQUARDA. A última fase de surgimento de A gaia Ciência. In: Cadernos Nietzsche, P. 75-93.

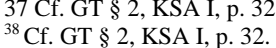

39 Cf. GT § 1 . 
cia representaria para o processo civilizatório e à soberania do indivíduo. Se os gregos tivessem sido completamente enredados e seduzidos por essa teia $d_{e}$ esquecimento e êxtase selvagem, talvez tivessem sucumbido como os melancólicos etruscos. ${ }^{40}$ Nietzsche parece criar, com essa breve menção à morte dos etruscos, uma espécie de contra-imagem ao que ele pretende acentuar nos gregos, ou seja, a habilidade destes para transformar a experiência com a imediaticidade, com todo horror aí experimentado ou vislumbrado, em mediação artística. Essa idéia se repetirá quando, tomando uma bela imagem do Hamlet de Shakespeare, Nietzsche descrever os terríveis efeitos sobre o homem, provocados pelo olhar que penetrou fundo demais na verdade dionisíaca, pois tão logo a consciência retorna à realidade, esta é sentida como náusea. $\mathrm{O}$ resultado desastroso, seja para a cultura, seja para o indivíduo, seria a irrupção de um ânimo ascético negador da vontade: "agora nenhum consolo produz mais efeito, o desejo vai mais além de um mundo depois da morte, mais além dos deuses inclusive, a existência é negada, juntamente com seu resplandecente reflexo nos deuses ou em um mais além imortal. Consciente da verdade intuída, agora o homem vê em todas as partes unicamente o espantoso absurdo do ser $[\ldots . ., 41$

No entanto, na interpretação de Nietzsche, os gregos não sucumbiram àquele fator de desequilíbrio e perigo supremo representado pela ruptura dos liames unificadores dos fragmentos que, juntos, constituem a identidade; não ultrapassaram as fronteiras seguras que os separavam, enquanto espectadores dessas festividades bárbaras, daqueles que, intoxicados pela "beberagem de bruxas", regrediam até a completa identificação com as bestas mais selvagens. ${ }^{42}$ Como foi possível aos gregos permanecerem nessa posição de um seguro distanciamento, isso, explica Nietzsche, só teria sido alcançado graças à figura de Apolo, que sempre se incumbira de erguer contra tal inimigo devastador a cabeça de Medusa de seu escudo protetor. 43

É preciso compreender que, para Nietzsche, existiria um "abismo enorme" separando esse dionisismo bárbaro e o grego dionisíaco, ${ }^{44}$ o qual precisou se submeter à pressão de um "tratado de paz", de certa forma imposto pelas forças apolíneas da ordem e da medida: ${ }^{45}$ em solo grego, Dioniso teve necessidade de tornar-se apolíneo, como vimos no fragmento póstumo citado

40 Cf. GT $\$ 3$.

41 Cf. GT \& 7. KSA I, p. 56-57, onde Nietzsche fala dos perigos para o homem que vivenciou o êxtase do estado dionisíaco.

42 Cf. GT $\& 2$.

43 Cf. GT \& 2, KSA I, p. 32. Segundo o mito, a cabeça da Medusa aparecia estampada no escudo de Apo $0^{\text {io. }}$

44 Cf. GT $\$ 2$, KSA I, p. 31 anteriormente, ou seja, precisou quebrar essa "vontade de monstruoso", submetendo-se à vontade de medida e contenção na forma exigida por Apolo. Comparando a maneira como o poder dionisíaco se revelou sob a pressão desse tratado de paz, frente às festividades bárbaras e "sua regressão do homem ao tigre e ao macaco", as orgias dionisíacas dos gregos devem ser vistas como fenômeno estético, pois nelas a essência da natureza se expressaria simbolicamente, graças a todo um mundo novo de símbolos, a todo o simbolismo corporal, da boca, do rosto, da palavra cantada, do gesto que move ritmicamente os membros, compondo um bailar que traduziria o próprio pulsar mais íntimo da natureza. ${ }^{46} \mathrm{O}$ que era imediaticidade pura se transforma em "imediaticidade mediada", em arte. ${ }^{47}$

Um leitor que passasse muito tempo envolvido com $O$ nascimento $d a$ tragédia, deixando-se impregnar por todo esse cenário carregado de tons místicos e metafísicos, no qual Nietzsche instala a problemática da arte, sem arriscar nenhuma incursão por textos posteriores, pode levar um choque ao se aproximar de escritos como Para além de bem e mal (JGB) ou Para a genealogia da moral (GM), obras de 1886 e 1887, respectivamente, ou de alguns dos mais significativos fragmentos póstumos desta década, dedicados à arte ou a temáticas correlatas. Não apenas o tom mudou muito, mas, para o que interessa aqui, mudou a imagem do deus da embriaguez, o agora desgarrado Dioniso. ${ }^{48}$ Que se tome como exemplo a paradigmática passagem de "Incursões de um extemporâneo", da obra Crepúsculo dos [ídolos, de 1888, na qual Nietzsche aproxima os nomes de Goethe e Dioniso para falar do "grande estilo': ${ }^{49}$

Goethe não um acontecimento alemão, mas sim um acontecimento europeu: uma tentativa grandiosa de superar o século dezoito mediante uma volta à natureza, medi-ante uma ascensão à naturalidade do Renascimento, uma espécie de autosuperação por parte daquele século. Ele levava dentro de si os instintos mais fortes deste: a sentimentalidade (Gefühlsamkeit), a idolatria com respeito à natureza, o caráter anti-histórico, idealista, irreal e revolucionário [...]. Recorreu à história, à ciência natural, à Antigüidade, inclusive a Espinosa, e, sobretudo, à atividade prática; cercou-se simplesmente de horizontes fechados; ele não se desligou da vida, se colocou dentro dela; ele não foi desanimado e tomou para si, sobre si, dentro de si, todo o possível. O que ele queria era totalidade; ele combateu a separação entre razão, sensibilidade, sentimento, vontade [...] ele se disciplinou para a totalidade, criou a si mesmo...

46 Cf. GT \& 2, KSA I, p. 33-34.

47 Vermittelte Unmittelbarkeit. Cf. FIGAL. Nietzsche. Eine philosophische Einführung, especialmente o capítulo "Vermittelung des menschlichen Künstlers", p. 77-102.

48 Cf. 14 [47], da primavera de 1888, KSA XIII, p. 241; também 14 [117], do mesmo período, KSA XIII, p. 293-294. 49 Quanto ao "grande estilo", cf. 14 [61], da primavera de 1888, KSA XIII, p. 246-248. Cf. também AKIYAMA.
Nietzsche Idee des "grossen Stils". In: Nietzsche-Studien 3, p. 105-114. 
Goethe foi um realista convicto, em meio a uma época de sentimentos irreais: ele disse sim a tudo que nela lhe era afim [...] Goethe concebeu um homem forte, de ${ }^{c}$ ultura elevada, hábil em todas as atividades corporais, que tem as rédeas de si mesmo, que sente respeito por si mesmo, ao qual é permitida a ousadia de desfrutar o âmbito inteiro e a inteira riqueza da naturalidade, que é forte o bastante para essa liberdade [...] Um tal espírito que se tornou livre está imerso no todo com um fatalismo alegre e confiante, na crença de que apenas o individual é reprovável, de que no seu conjunto tudo se redime e se afirma - ele não nega nada mais... Mas uma tal crença é a mais elevada de todas as crenças possíveis: eu a batizei com o nome de Dioniso. 50

Duas imagens destacam-se aqui como proeminentes: a ascensão à naturalidade e a idéia de totalidade. Compreendê-las pode contribuir para que se visualize melhor a reflexão filosófica oculta agora sob o nome de Dioniso, assim como para que se vislumbre algo dos impasses circundando a problemática da arte na obra tardia do filósofo. Ascender à natureza e à naturalidade afirma algo de paradoxal e que pode causar certo estranhamento, afinal o termo "ascensão" é usualmente interpretado como movimento de distanciamento da natureza, não de encontro com ela. A idéia de elevação sempre esteve ligada, na história da filosofia e da religião, em nossa cultura judaico-cristã ocidental, a um afastamento do que é "menor", de um estágio primitivo e primeiro, em direção a algo mais complexo, superior. A própria idéia de cultura, por exemplo, constituiu-se numa oposição à natureza; da mesma forma $\mathrm{o}$ supra-sensível, o divino, o espírito, os quais sempre foram imaginados em frontal oposição ao natural, aos sentidos, aos instintos, ao corpo e suas demandas. A grandeza humana, e da cultura como um todo, deveria ser avaliada e medida exatamente na proporção de seu distanciamento da natureza e dos "estados naturais", como por exemplo aqueles nos quais o homem mais se assemelharia aos animais ou às forças incontroláveis e imprevisíveis daquela.

Nietzsche, entretanto, pensa o seu Tipo mais elevado, aquele capaz da crença mais elevada de todas as possíveis, como um raro esforço humano de "ascender (Hinaufkommen) à natureza e à naturalidade mais elevada, livre, terrível inclusive, que joga, que pode (darf) jogar com grandes tarefas". ${ }^{51}$ Tanto Goethe como esse ideal de virtude do Renascimento são imagens incorpo ${ }^{-}$ radas à reflexão nietzscheana da cultura por uma técnica de exposição extraída muito mais das artes literárias do que propriamente do usual aparato conceit ${ }^{\text {ual }}$ da filosofia. Goethe incorpora uma espécie de "realismo trágico", capaz de unir a recusa a qualquer distanciamento das complexas tensões que atraves" sam natureza e história a um ideal de totalidade que combate toda separação entre razão e sensibilidade; instinto e espírito; idealismo e vontade de criar. Condensa-se nessa imagem quase heróica um conjunto de idéias recorrentes na obra tardia do filósofo, e repetidas por ele no ideal do "grande estilo". A elevação do humano é aí identificada à conquista da totalidade artística de si mesmo, ou seja, corresponderia à capacidade de orquestração dos instintos, paixões, desejos e todas as forças que constituem a complexa e multifacetada existência daquele que é Individuum.

Como se tornar legislador de si mesmo? Essa parece ser a questão comum à reflexão filosófica tanto de Platão como de Nietzsche sobre a arte. Em que medida a arte desempenharia aí algum papel relevante? Já em sua Considera-

Extemporânea sobre a história, escrita em 1874, Nietzsche referia-se aos grandes perigos para indivíduo e cultura, quando o homem não desenvolve capacidade plástica, artística, de modelar a si próprio, assimilando todo estranho e estrangeiro e impondo a si mesmo ou à sua cultura uma unidade de estilo. ${ }^{52}$ Segundo podemos ler aí, justamente o grande mal a ser denunciado na modernidade seria uma generalizada "fraqueza de personalidade" e perigosa contradição entre conteúdo e forma, o que caracterizaria uma ausência de "unidade do estilo artístico em todas as expressões da vida de um povo", conduzindo a uma miserável fissura entre forma e conteúdo. ${ }^{53}$

Tanto nesse escrito como na imagem do Tipo Goethe, Nietzsche defenderia a mesma idéia: quanto maior o autocontrole da força, o domínio sobre si mesmo, quanto maior a destreza na disciplina interior, maior será o âmbito da realidade a ser desfrutado, pois apenas aquele que tem o domínio da própria força pode tomar para si o desgastado e já conhecido para remodelá-lo, extraindo de sua aparente simplicidade toda possível profundidade. ${ }^{54}$ Apenas aquele que tem as rédeas de si mesmo responde ao desafio da criação da "virtude única", esse eixo de comando sobre si e fundamento para a criação de limites bem definidos que protejam o indivíduo da perigosa dissolução ou dispersão no fluxo eterno de vida e morte, no qual tudo se encontra mergulhado. ${ }^{55} \mathrm{O}$ "grande estilo" seria justamente aquilo a lhe permitir desfrutar da inteira com${ }^{\mathrm{pl}}$ exidade e riqueza da realidade, tornando-se senhor sobre o caos daquilo que se é, impondo forma a seu caos — necessidade tornada forma —, lançando,

52 Cf. Segunda Consideração Extemporânea. "Da utilidade e desvantagem da história para a vida" § 1. In: KSA 5 Cf. Idem. $\$ 4$, p. 274-275.

54 Cf. Idem. \& 6, p. 294

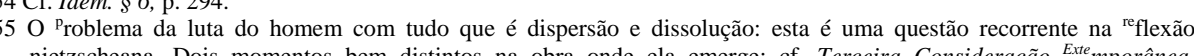
nietzscheana. Dois momentos bem distintos na obra onde ela emerge: cf. Terceira Consideração Exte mporânea "Schopenhauer como educador" § 5. KGW III 1, p. 375; também o Prólogo para Humano, dem asiado humano I., escrito em 1886; e § 338 de A gaia ciência, de 1882. 
assim, o olhar na direção daquilo que concede à existência o caráter estável e a simplicidade das fórmulas matemáticas: a arte e o sagrado. ${ }^{56}$

O "grande estilo" aparece como, simultaneamente, uma utopia para humano e um desafio para a cultura, demandando toda força escultórica no trabalho de modelar a maleável matéria do caráter. ${ }^{57}$ Constituído como é por uma complexidade de forças e possibilidades, o homem se vê coagido a criar uma síntese viável de ser vivida, sob o risco de sucumbir em meio à tensão que não domina. Essa habilidade de orquestração de apelos contraditórios e conflitantes da existência, da história e da natureza, aparece de forma recorrente na história do pensamento moral, de Platão a Nietzsche, associada a uma capacidade plástica transformadora e propiciadora de forma, da própria forma, ${ }^{58}$ a forma do que se é, da sua virtude e crença e, por isso mesmo, da cultura. O enigma do domínio da força, da disciplina para o aprendizado espiritual de si mesmo remeteria àquele mistério da síntese de vontade de monstruoso e vontade de mesura e forma, segundo o quer Nietzsche, alcançada por meios artísticos pela cultura grega.

Em sintonia com as preocupações de seu mestre, Nietzsche retoma sua questão de fundo, aquela que indaga pela relação entre arte, formação do caráter autônomo e soberania da cultura. Também com ele, insiste na importância central do ensinamento para o domínio das paixões como único caminho possível ao homem para dar ele próprio estilo a seu caráter, em meio à diversidade e profusão de possibilidades oferecidas pela natureza e pela história: dar estilo a seu caráter, reza uma passagem de A gaia ciência, essa a grande e rara arte, "praticada por quem avista tudo o que sua natureza tem de forças e fraquezas e o ajusta a um plano artístico", demonstrando com essa consumação artística de uma síntese, "como foi a coação de um só gosto que predominou e deu forma, nas coisas pequenas como nas grandes". ${ }^{59}$ São as naturezas artísticas,

56 Cf. Segunda Consideração Extemporânea. "Da utilidade e desvantagem da história para a vida", § 10, também fragmento póstumo intitulado "Vontade de Poder como arte. 'Música' - e o grande estilo": 14 [61], da primavera de 1888. In: KSA XIII, p. 246-248.

57 Maleável, ao menos, como o distinguem bem tanto Platão como Nietzsche, quando se trata da alma jovem Justamente por sso o filósofo tem sua atenção voltada para o problema da educação da juventude. Com o passar dos anos enrijece 58 Não há espaço aqui para discutir isso mais deta sua rigidez.

pe dirijam aos texto antigos estóicos, - torna-te. Qquele a estu és" - e transformo", que claramente ressoará na sentença tomada por Nietzsche de Píndaro - torna-te aquele que tu es - e transformada em seu "tema, repete Plotino: "esculpir sua própria estátua". Trata-se a forma à sua alma com exercícios espirituais, da mesma maneira que esculpe seu corpo com a ginástica. Cf. HADOT. Exercices spirituels et philosophie antique, aqui p. 48-49. 200

59 Cf. FW § 290, aqui na tradução de Paulo César de Souza: A gaia ciência. São Paulo: Cia. das Letras, p. 195. exemplificadas na figura de um Goethe, aquelas a encontrar sua força e alegria no movimento interior de constrangimento e consumação da diversidade sob sua própria lei, sob uma única lei, enquanto "inversamente, são os caracteres fracos, nada senhores de si, que odeiam o constrangimento do estilo", ${ }^{60}$ por-que este demanda, sem dúvida, grande esforço e concentração em objetivos, rumos e sentidos próprios, resistindo a toda fragmentação e dispersão.

Mas a consonância entre Nietzsche e o filósofo grego revela-se ainda mais surpreendente quando recordamos aquela acusação feita por Platão aos poetas trágicos de regarem nossos monstros interiores com os efeitos da imitação poética, em vez de secá-los, erigindo-os a nossos soberanos ( $A$ República, 606d), instaurando, dessa forma, na alma de cada indivíduo o mau governo ao lisonjear a parte irracional, "que não distingue entre o que é maior e o que é menor" (605c). O grande perigo aqui, alerta o filósofo, é aquele de formarmos escravos: "alguém que tem a sua melhor parte tão débil por natureza, que não é capaz de comandar os monstros que nele habitam, antes os acalenta e a única coisa que aprende é a adulá-los" (590c-d). Os leitores de Para a genealogia da moral devem sentir de imediato a proximidade em que nos encontramos das reflexões nietzscheanas sobre o confronto entre o modo de valorar aristocrático e o produzido pelo "instinto de rebanho" daqueles que, impotentes para o domínio de si e para a criação de valores a partir da afirmação de si mesmos, alcançam apenas reação. ${ }^{61}$

O grande perigo, concorda Nietzsche, é o de se arruinar a exceção em proveito da regra, graças a um despreparo para a verdadeira formação (Bildung) da virtude única (virtù),62 pois esta exige justamente aquilo exemplificado pela figura de Goethe: a orquestração de todas as forças em conflito seja na interioridade humana, seja na natureza ou na história, tomando as rédeas de si mesmo, disciplinando a si mesmo para essa totalidade. Sem dúvida alguma, uma operação espiritual ousada que implicaria uma sabedoria artística para a "espiritualização das paixões". ${ }^{63} \mathrm{O}$ domínio sobre as paixões, não seu enfraquecimento ou extirpação, este o único objetivo possível quando se almeja o indivíduo soberano e o autogoverno da cidade: "quanto maior é a força dominadora de nossa vontade, tanto mais liberdade é lícito ser dada às paixões. O grande homem é grande pelo espaço de liberdade de suas paixões: porém, ele é suficientemente forte para fazer desses monstros seus animais domésticos" ${ }^{64}$ Vislumbra-se aqui

60 Ibidem, p. 196.

61 Cf. I I dissertação de GM

[6], da primavera/verão de 63 Cf. Crepúsculo dos ídolos (GD). "Moral como contra-natureza"

64 Cf. Fragmento Póstumo 16 [7], da primavera de 1888, KSA XIII, p. 485. Esta sentença é praticamente a 
algo da enorme dívida de Nietzsche para com toda uma linhagem de pensadores que, de Sócrates ao estoicismo cristão, identifica como o grande desafio do espírito aquele da educação do homem para o comando de si mesmo.

Como se respondesse a Platão, em parte com ele acordando, em parte buscando ultrapassá-lo, Nietzsche compõe, ao longo de uma década, seu conceito de "grande estilo". Como pano de fundo a mesma utopia do filósofo.. legislador e seu embate com a cultura dominante em busca da afirmação de uma outra espécie de espíritos, bem diversos daqueles hegemônicos em seu tempo. ${ }^{65}$ Para tal, defende ele, deve-se cultivar no homem o domínio da própria força, domínio que é, sobretudo, orquestração de instintos e impulsos conflitantes, mesmo de tendências excludentes: "tornar-se senhor sobre o caos daquilo que se é; a seu caos impor tornar-se forma; necessidade tornada forma", como lembra ele em seu fragmento sobre música e o "grande estilo". ${ }^{66}$

Apesar de ver em Platão a figura de um dos "grandes moralistas" da história do Ocidente, ou seja, como alguém que buscou inventar e ensinar o mecanismo de domínio do homem sobre si próprio e sobre a natureza, por meio da criação de virtudes norteadoras, como fica claro em diversas passagens de sua obra, ${ }^{67}$ Nietzsche coloca-se, com a construção de seu conceito de "grande estilo", numa posição de tensão frente ao filósofo grego. Simultaneamente pretendendo-se seu continuador e opositor, como fica claro, por exemplo, no capítulo "Moral como contra-natureza", de Crepúsculo dos ídolos. Sem se dirigir nominalmente a Platão e discursando aparentemente apenas sobre a moral, Nietzsche faz aqui uma veemente defesa do "grande estilo", como a habilidade "artística" para a espiritualização das paixões, como uma sabedoria de orquestração das vivências humanas com a precariedade e, simultaneamente, profusão da realidade, como que sugerindo que retomemos o diálogo de Platão com seu jovem discípulo sobre os perigos representados pelos poetas que insistem em alimentar e fortalecer o "monstro de mil formas" (589a), representando em suas imagens o lado mau, o irracional, a parte irascível do homem (604d-605e), para então nos indagarmos se aquele "velho monstro da moral", ${ }^{6}$ Platão, tinha mesmo razão em defender como necessária a exclusã ${ }^{0}$ da cidade de uma arte de tal espécie $\left(607\right.$ b), como única forma de exerce ${ }^{\mathrm{r}}$ sobre ela o justo e bom governo?

mesma que inicia um outro fragmento póstumo do outono de 1887: 9 [139] KSA XII, p. 414. Também sobr o tema, cf. 11 [353], do inverno de 1887/8, KSA XIII.

65 Cf. GM. II a dissertação § 24; JGB § 211, 212, 229, 230.

67 Cf. por exemplo: JGB \& 186-191; também um importante fragmento póstumo de novembro 1887/maço 1888, intitulado

"Do domínio da virtude - De como se ajuda a virtude a chegar ao domínio: Um tracta $^{\text {tus }}$ politicus": 11 [54], KSA XIII, p. 24-27.

68 Cf. GD. "Moral como contra-natureza" § 1.
Para encerrar, seria pertinente insistir em que nunca se perca de vista a questão da arte trágica, quando se trata desse riquíssimo embate entre Nietzsche e seu mestre Platão. Não apenas no sentido estrito da poesia e da apresentação teatral do drama criado por poetas como Esquilo, Sófocles ou Eurípedes, mas sobretudo naquele da "pergunta trágica", aquela que aponta para o absurdo da indeterminação do humano: como pode o homem prosseguir querendo e cri-ando, sendo ele como é um ser de paradoxo? Um ser assentado sobre um vazio absoluto? Se pensada assim, a questão trágica pode ser lida como instigante cenário de embate entre dois filósofos-legisladores em defesa de uma "forma de pensar nobre", que fixe regras para o futuro, "que em nome do futuro trate a si própria e a todo presente dura e tiranicamente; uma forma de pensar sem hesitação, uma forma de pensar "amoral" (unmoralisch), que queira cultivar na grandeza as boas e ruins características do homem, igualmente, porque ela se julga capaz da força para colocar ambas no lugar certo, no lugar onde são reciprocamente necessárias". ${ }^{69}$ As diferenças aqui entre os contendores não devem nos ocultar estarmos diante do mesmo esforço, uma mesma arte:

Mas os autênticos filósofos são comandantes e legisladores: eles dizem "assim deve ser"!, eles determinam o para onde? E para quê? do ser humano, e nisso têm a seu dispor o trabalho prévio de todos os trabalhadores filosóficos, de todos os subjugadores do passado estendem a mão criadora para o futuro, e tudo que é e foi torna-se para eles um meio, um instrumento, um martelo. Seu "conhecer" é criar, seu criar é legislar, sua vontade de verdade é - vontade de poder. Existem hoje tais filósofos? Já existiram tais filósofos? Não têm que existir tais filósofos?... ${ }^{70}$

\section{Referências}

AKIYAMA, Hideo. Nietzsches Idee des "grossen Stils". In: Nietzsche Studien. (Hrsg.). MÜLLER-LAUTER, Wolfgang; MONTINARI, Mazzino; WENZEL, Heinz. Berlin/ New York: Walter de Gruyter, 3, 1974. p. 105-114.

BROBJER, Thomas H. Nietzsche's Ethics of Character. Uppsala: Uppsala University, 1995.

CONFORD, E M. Principium Sapientiae. As origens do pensamento filosófico grego. 2. ed. Trad. Maria Manuela Rocheta dos Santos. Lisboa: Fundação Calouste Gulbenkian, 1981

DIAS, Rosa Maria. Nietzsche e a música. Rio de Janeiro: Imago, 1994.

DIXSAUT, Monique. Nietzsche lecteur de Platon. In: NESCHKE-HENTSCHKE, Ada

(Ed.). Images de Platon et lectures de ses oeuvres. Louvain/Paris: Editions Peeters, 1997.

FIGAL, Günter. Nietzsche - Eine philosophische Einführung. Stuttgart: Reclam, 1999. 
GAGNEBIN, Jeanne Marie. Sete aulas sobre linguagem, memória e história. Rio de Janeiro: Imago, 1997.

GOMBRICH, E.H. Arte e ilusão. Trad. Raul de Sá Barbosa. São Paulo : Martins Fontes, 1986.

HADOT, Pierre. Exercices spirituels et philosophie antique. Paris: Etudes Augustiniennes, 1987.

HEIDDEGER, Martin. Nietzsche. v. I. Pfullingen: Verlag Günter Neske, 1961.

HERRERO, David Estrada. Estética. Barcelona: Editorial Herder, 1988.

KOFMAN, Sarah. Nietzsche and metaphor. Trad. Duncan Large. Londres: Athalone Press, 1993.

LICHTENSTEIN, Jacqueline. A cor eloqüente. São Paulo: Siciliano, 1994 NIETZSCHE, Friedrich. Sämtliche Werke. Kritische Studienausgabe. (KSA). (Hrsg.) G. Colli/M. Montinari. Berlin: Walter de Gruyter, 1988.

Sämtliche Werke. Kritische Gesamtausgabe. (KGW). (Hrsg) G.

Colli/M. Montinari. Berlin: Walter de Gruyter, 1968.

Vorlesungenaufzeichnungen (WS 1871/72-WS 1874/75). In: Kritische Gesamtausgabe. (Hrsg.). Fritz Bornmann. Berlin/New York: Walter de Gruyter, 1995. . El nacimiento de la tragedia. 7. ed. Trad. e notas Andrés Sánchez Pascual. Madrid: Alianza Editorial, 1985.

. Além do bem e do mal. Trad., notas e posfácio Paulo César de Souza. São Paulo: Cia. das Letras, 1992.

Genealogia da moral. 2. ed. Trad. e notas Paulo César de Souza. São

Paulo: Brasiliense, 1988.

. A gaia ciência. Trad., notas e posfácio Paulo César de Souza. São

Paulo: Cia. das Letras, 2001.

. Humano demasiado humano. Trad., notas e posfácio Paulo César de Souza. São Paulo: Cia. das Letras, 2000.

OTTMANN, Henning (Hrsg.). Nietzsche Hadbuch — Leben, Werk, Wirkung. Stuttgart/Weimar: J. B. Metzler, 2000.

PANOFSKY, Erwin. Significado nas artes visuais. Trad. Maria Clara F. Kneese e J. Guinsburg. São Paulo: Perspectiva, 1976.

PLATÃO. A República. 8. ed. Trad., introd. e notas Maria Helena da Rocha Pereira. Lisboa: Fundação Calouste Gulbenkian, 1996.

POLLITT, J. J. Art and experience in classical Greece. Cambridge: Cambridge University Press, 1996.

SALAQUARDA, Jörg. A última fase de surgimento de A gaia Ciência. Trad. Barbar ${ }^{a}$ Salaquarda e Oswaldo Giacoia Junior. In: Cadernos Nietzsche. Departamento de filosofia da USP, São Paulo, n. 6, 1999, p. 75-93.

. Einleitung. Zum Seminar Ober "Nietzsche contra Wagner". In: GERLAC ${ }^{\mathrm{H},}$ Hans-Martin; EICHBERG, Ralf; SCHMIDT, Hermann J. (Org.). Nietzscheforsch ${ }^{\text {ung }}$. v. II. Berlin: Akademie Verlag, 1994, p. 255-257.

SCHUHL, Pierre-Maxime. Platon et l'art de son temps. Paris: PUF, 1952.

\section{ÉTICA, CIÊNCIA E TECNOLOGIA}

Ivan Domingues*

RESUMO $O$ artigo visa pensar a relação entre ética, ciência e tecnologia, enfatizando o problema de sua revinculação depois da cisão entre os juízos de fato e os juízos de valor, ocorrida no início dos tempos modernos. Uma vez examinada a ética da aristocracia guerreira e a moral do santo, procura-se delinear o caminho tomando como referência a ética da responsabilidade, cujo protótipo é a moral do sábio, desaparecido no curso dos tempos modernos, em razão da fragmentação do saber e do advento do especialista. Ao fim do estudo, é discutida a relação entre a ética e a metafísica, com o intuito de ajustar a questão antropológica à perspectiva cosmológica, bem como de fornecer as bases de um novo humanismo, objetivando a humanização da técnica e a geração de um novo homem, alfabetizado em ciência, tecnologia e humanidades.

Palavras-chave ética, ciência, tecnologia, nihilismo

ABSTRACT The article aims at thinking the relation among ethics, science and technology, emphasizing the problem of their re-tying, after the division into judgments of fact and judgments of value, wich happened in the begininning of modern times. Since the warlike aristocracy's ethics and the saint man's moral are examined, it tries to outline its way, taking as a reference the ethics of responsability, whose prototype is the wise man's moral, which disappeared in the course of modern times, due to the fragmentation of knowing and the advent of the specialist. At the end of the study, the rela-

* Professor do Departamento de Filosofia da Universidade Federal de Minas Gerais.

Artigo recebido em jul./2003 e aprovado em abr./2004.

KRITERION, Belo Horizonte, $n^{\circ}$ 109, Jun/2004, p. 159-174 